\title{
Nitrate leaching through climatologic water balance in a fertigated coffee plantation ${ }^{1}$
}

\author{
Rafael Pivotto Bortolotto ${ }^{2}$ Isabeli Pereira Bruno ${ }^{3}$, Durval Dourado-Neto ${ }^{4}$, Luís Carlos Timm ${ }^{5}$, \\ Adilson Nunes da Silva ${ }^{6}$, Klaus Reichardt ${ }^{7}$
}

\begin{abstract}
Nitrate losses from soil profiles by leaching should preferentially be monitored during high rainfall events and during irrigation when fertilizer nitrogen applications are elevated. Using a climatologic water balance, based on the models of Thornthwaite and Penman Monteith for potential evapotranspiration, drainage soil water fluxes below the root zone were estimated in a fertigated coffee crop. Soil solution extraction at the depth of $1 \mathrm{~m}$ allowed the calculation of nitrate leaching. The average nitrate concentration in soil solution for plots that received nitrogen by fertigation at a rate of $400 \mathrm{~kg} \mathrm{ha}^{-1}$, was $5.42 \mathrm{mg} \mathrm{L}^{-1}$, surpassing the limit of the Brazilian legislation of $10.0 \mathrm{mg} \mathrm{L}^{-1}$, only during one month. For plots receiving $800 \mathrm{~kg} \mathrm{ha}^{-1}$ of nitrogen, the average was $25.01 \mathrm{mg} \mathrm{L}^{-1}, 2.5$ times higher than the abovementioned limit. This information indicates that nitrogen rates higher than $400 \mathrm{~kg} \mathrm{ha}^{-1}$ are potentially polluting the ground water. Yearly nitrate amounts of leaching were 24.2 and $153.0 \mathrm{~kg} \mathrm{ha}^{-1}$ for the nitrogen rates of 400 and $800 \mathrm{~kg} \mathrm{ha}$ ${ }^{1}$, respectively. The six times higher loss indicates a cost/benefit problem for coffee fertigations above $400 \mathrm{~kg} \mathrm{ha}^{-1}$.
\end{abstract}

Key words: Thornthwaite, Penman-Monteith, evapotranspiration, deep drainage, urea.

\section{RESUMO}

\section{Lixiviação de nitrato por meio do balanço hídrico climatológico na cultura de café fertirrigada}

As perdas de nitrato no perfil do solo por lixiviação devem ser monitoradas preferencialmente em ocasiões de altas precipitações pluviométricas e irrigações quando o uso de insumos nitrogenados é elevado. Foi utilizado o balanço hídrico climatológico empregando os modelos de Thornthwaite e Penman Monteith na obtenção da estimativa de evapotranspiração potencial para calcular os fluxos de drenagem de água abaixo da zona de raiz em lavoura de café fertirrigada. A extração da solução do solo a uma profundidade de $1 \mathrm{~m}$ permitiu o cálculo do nitrato lixiviado. A concentração de nitrato na solução do solo nas parcelas que receberam $400 \mathrm{~kg} \mathrm{ha}^{-1}$ de nitrogênio foi em média 5,42 mg $\mathrm{L}^{-1}$, ultrapassando o limite da legislação brasileira de $10,0 \mathrm{mg} \mathrm{L}^{-1}$ em apenas um mês. Para as parcelas em que se aplicaram $800 \mathrm{~kg} \mathrm{ha}^{-1}$ de nitrogênio, o valor médio foi de $25,01 \mathrm{mg} \mathrm{L}^{-1}$, que é 2,5 vezes maior do que o limite supraindicado. Essa informação mostra que doses de nitrogênio superiores a $400 \mathrm{~kg} \mathrm{ha}^{-1}$ são potencialmente poluidoras de águas subterrâneas. Os montantes anuais de lixiviação de nitrato foram 24,2 e 153,0 kg ha-1 para aplicações de 400 e $800 \mathrm{~kg} \mathrm{ha}^{-}$ ${ }^{1}$ de nitrogênio, respectivamente. Essa perda seis vezes maior em ralação à menor aplicação indica um problema de custo/beneficio em fertirrigações acima de $400 \mathrm{~kg} \mathrm{ha}^{-1}$.

Palavras-chave: Thornthwaite, Penman-Monteith, evapotranspiração, drenagem profunda, ureia.

Received: 06/10/2011; Accepted: 31/10/2013.

'Part of the first author's Doctor Science Thesis, USP/ESALQ. Work funded by CNPq and FAPESP.

${ }^{2}$ Agronomist Engineer, Doctor of Science. Departmento de Solos, Universidade Federal de Santa Maria, Avenida Roraima, 100, 97105-900, Santa Maria, Rio Grande do Sul, Brazil. rpbortolotto@yahoo.com.br (corresponding author).

${ }_{3}^{3}$ Agronomist Engineer, Doctor of Science. Instituto Agronômico do Paraná, Rodovia Celso Garcia Cid, Km 375, 86001-970, Londrina, Paraná, Brazil. isabelibruno@ gmail.com ${ }_{4}^{4}$ Agronomist Engineer, Doctor of Science. Departamento de Produção Vegetal, Escola Superior de Agricultura "Luiz de Queiroz", Universidade de São Paulo, Caixa Postal 9, 13418-900, Piracicaba, São Paulo, Brazil. ddourado@usp.br

${ }_{5}^{5}$ Agricultural Engineer, Doctor of Science. Departmento de Engenharia Rural, Universidade Federal de Pelotas, Campus Capão do Leão, s/n, Caixa Postal 354, 96001-970, Pelotas, Rio Grande do Sul, Brazil. lctimm@ufpel.edu.br

${ }^{6}$ Agronomist Engineer, Master of Science. Escola Superior de Agricultura "Luiz de Queiroz”, Universidade de São Paulo, Caixa Postal 9, 13418-900, Piracicaba, São Paulo, Brazil. nunesadil@yahoo.com.br

${ }^{7}$ Agronomist Engineer, Doctor of Science. Centro de Energia Nuclear na Agricultura, Universidade de São Paulo, Avenida Centenário, 303, Bairro São Dimas, Caixa Postal 96, 13400-970, Piracicaba, São Paulo, Brazil. klaus@cena.usp.br 


\section{INTRODUCTION}

Irrigated coffee plantations have increased significantly in the last years in Brazil, mainly in coffee growing areas, which traditionally were not used to grow this sort of crop. Reports have shown an increase of about $44 \%$ in the productivity of highly dense coffee plantations under irrigation (Scalco et al., 2011). Fertigation is the combination of irrigation with fertilizer application. In these new growing areas, it is common to find extensive areas irrigated by central pivot systems, used for fertigation. The advantage of such systems is the joint application of water and fertilizer; however with a potential to promote leaching.

During the last two decades, coffee cultivation in Brazil was extended from traditional coffee growing areas to the Brazilian savanna or "cerrado" plains, as those of Bahia state. Coffee growers in this region have been using nitrogen (N) rates (of the order of $600-800 \mathrm{~kg} \mathrm{ha}^{-1}$ year $^{-1}$ of $\mathrm{N})$ far above those applied in other coffee producing areas (150 - $450 \mathrm{~kg} \mathrm{ha}^{-1}$ year $^{-1}$ of N) (FAO, 2010; Bortolotto et al., 2011; Bruno et al., 2011; Neto et al., 2011). Without any scientific basis for these excessively high $\mathrm{N}$ application rates, losses to the environment are likely to be occurring (Milroy et al., 2008; Sitthaphanit et al., 2009).

The concentration of nitrate $\left(\mathrm{N}-\mathrm{NO}_{3}{ }^{-}\right)$in the groundwater is generally high in areas where farmers seek higher returns without considering the occurrence of excesses in the application of doses of $\mathrm{N}$ fertilizers. Therefore, it is important to rationalize the application of these fertilizers, a measure that ensures sustainability of the environment. The $\mathrm{N}_{-} \mathrm{NO}_{3}{ }^{-}$is the most discussed ion in the literature, in relation to ground water pollution due to its high solubility in water and potential for leaching (Hansen et al., 2000; Assadi et al., 2002; Basso et al., 2005; Jadoski et al., 2010).

Leaching happens when nutrients are carried out of the root zone, to greater depths in the soil profile (Silva et al., 2006; Jadoski et al., 2010; Bortolotto et al., 2012), and these nutrients may reach ground water. The concentration of $\mathrm{N}^{-\mathrm{NO}_{3}}{ }_{3}^{-}$in the soil has its origin mostly in the mineralization process of organic matter and in the use of $\mathrm{N}$ fertilizers applied to the soil. When this ion is not absorbed by plant roots or immobilized by the soil microbiota, it remains available for the leaching process, mainly in soils of predominant negative charge (Primavesi et al., 2006).

Soils of coarser texture as the sandy ones of the Brazilian savannah or "cerrado", which are located in central Brazil areas, have the tendency to allow more intense leaching of ${\mathrm{N}-\mathrm{NO}_{3}}^{-}$(Correa et al., 2006). For these soils, the threshold for portability of the ground water is $10 \mathrm{mg}$ $\mathrm{L}^{-1}$ of $\mathrm{N}^{-\mathrm{NO}_{3}}{ }^{-}$expressed as N (Brasil, 2004; Brasil, 2008).
The $\mathrm{N}^{-\mathrm{NO}_{3}}{ }_{3}^{-}$in the ground water is of worldwide concern (Stewart et al., 2006) and the main factors that influence its leaching are rainfall, irrigation, $\mathrm{N}$ application rates and soil texture (Andrade et al., 2009). Several of these factors have anthropic causes and can, therefore, be managed to minimize pollution effects and to maximize fertilizer uptake (Primavesi et al., 2002).

The losses of $\mathrm{N}_{-} \mathrm{NO}_{3}^{-}$by leaching are directly related with the concentration and intensity of drainage soil water fluxes, so that both have to be monitored when high doses of $\mathrm{N}$ fertilizers are applied during periods of intense rainfall and irrigation. Direct measurements of these parameters in the field are tedious and costly, so that alternatives that make use of climatologic data are many times welcome. Measurements of concentration of the N$\mathrm{NO}_{3}{ }^{-}$in the soil solution allow the calculation of losses by leaching, i.e., the potential of leaching of an agricultural system.

Thus, using a climatologic water balance in the application of the models of Thornthwaite and PennanMonteith to assess the potential evapotranspiration, the deep drainage soil water fluxes below the root zone was estimated. Measuring the concentration of $\mathrm{N}-\mathrm{NO}_{3}{ }^{-}$below the rooting depth, $\mathrm{N}$ leaching was estimated in a fertigated coffee crop over an area located in the central plains of Brazil, areas originally covered by savannah.

\section{MATERIAL AND METHODS}

The study was carried out in a fertigated coffee plantation under central pivot irrigation, in Barreiras, Bahia State, Brazil (11 ${ }^{\circ} 46^{\prime} \mathrm{S}$ and $45^{\circ} 43^{\prime} \mathrm{W}, 740 \mathrm{~m}$ above sea level). The crop was established nine years ago, on a very flat area, formerly occupied by savannah, locally called "cerrado".

The local climate is of the Aw type, corresponding to a tropical sub-humid class with summer rain and a welldefined dry winter. The rainfall varies between 800 to 1800 $\mathrm{mm}$ per year, and is concentrated from October to April (SEI, 1998).

In this region, doses of $\mathrm{N}$ fertilizers are extremely elevated, ranging from 600 to $800 \mathrm{~kg} \mathrm{ha}^{-1}$ year $^{-1}$ of $\mathrm{N}$, applied continuously in equal portions over the growing coffee cycle. Therefore, these areas present a high potential for $\mathrm{N}_{-} \mathrm{NO}_{3}^{-}$leaching, especially in the case of sandy soils that are very common in the region. The soil on the site is a "LATOSSOLO VERMELHO-AMARELO Alumínico típico" (Tables 1, 2 and 3) (Embrapa, 2006) and as a Typic Hapludox (Soil Survey Staff, 2010).

The leaching of $\mathrm{N}^{-\mathrm{NO}_{3}}{ }^{-}$was estimated during the period from August 1st 2008 (DAB $=0$ day after beginning) to July 31st 2009 (DAB = 365), carried out on a coffee (Coffea arabica L.) plantation, variety "Catuaí Vermelho". 
The crop was planted in January 2001 spacing $3.8 \mathrm{~m}$ on the rows and $0.5 \mathrm{~m}$ between plants, in a circular arrangement under a central pivot irrigation system (operated with low energy precision application LEPA sprinklers), covering a total area of 80 ha. It was fertilized during the first seven years with $\mathrm{N}$ applications of $600 \mathrm{~kg}$ $\mathrm{ha}^{-1}$ year $^{-1}$. The productivity of this farm was above the national average, in the order of $56 \mathrm{bags} \mathrm{ha}^{-1}(60 \mathrm{~kg}$ of benefited coffee beans bags). The irrigation was continuous over the year, at rates of 2 to $4 \mathrm{~mm}_{\text {day }}{ }^{-1}$ applied every other day, including all fertigation products. Table 4 displays climatic data of the site including directly measured rainfall ( $\mathrm{mm})$ and fertirrigation depths $(\mathrm{mm})$.

The sequential climatic water balance were calculated using the program developed by Rolim et al. (1998) for five-day periods, over the whole growing cycle 2008/2009, using the equation (1):

$\pm \Delta \mathrm{SWS}=\mathrm{P}+\mathrm{I}-\mathrm{ETa}+\mathrm{AC}-\mathrm{Q}-\mathrm{RO}$

Where:

$\Delta \mathrm{SWS}==$ changes in the soil water storage $(\mathrm{mm})$ at $1 \mathrm{~m}$ deep on the soil layer, assumed to contain the total coffee root system, based on the measured available water capacity of $86.4 \mathrm{~mm}$ (Table 2);

$\mathrm{P}=$ rainfall $(\mathrm{mm})$;

$\mathrm{I}=$ irrigation $(\mathrm{mm})$;

$\mathrm{ETa}=$ actual evapotranspiration $(\mathrm{mm})$;

$\mathrm{AC}=$ capillary water rise $(\mathrm{mm})$;

$\mathrm{Q}=$ drainage below the root zone $(\mathrm{mm})$;

$\mathrm{RO}=\operatorname{runoff}(\mathrm{mm})$.

In this study, rainfall and irrigation were considered jointly. Capillary water rise was taken as absent due to the very deep location of the water table (about $30 \mathrm{~m}$ ). Runoff was also considered null because the area is very flat, presenting an average slope of $0 \%$. The climatologic water balance program estimates a component called excess (excess = capillary water rise + drainage below the root zone + runoff) which, therefore, was considered equal to the drainage below the root zone. For estimations of actual evapotranspiration, the software Microsoft Excel operated with two models for the potential evapotranspiration:
Thornthwaite (Thornthwaite, 1948), and Penman-Monteith (Allen et al., 2006).

The experimental design was a completely randomized, with two treatments and four replicates, disposed over the circle number 4 of the central pivot. The treatments consisted of applications of $\mathrm{N}$ fertilizers doses: $\mathrm{T}_{400}(400$ $\mathrm{kg} \mathrm{ha}^{-1}$ of N), $76 \mathrm{~g}_{\text {plant }}^{-1}$ of $\mathrm{N}$, corresponding to $169 \mathrm{~g}$ plant $^{-1}$ of urea; and $\mathrm{T}_{800}\left(800 \mathrm{~kg} \mathrm{ha}^{-1}\right.$ of $\left.\mathrm{N}\right), 152 \mathrm{~g} \mathrm{plant}^{-1}$ of $\mathrm{N}$ or $338 \mathrm{~g} \mathrm{plant}^{-1}$ of urea, applied in equal portions every 14 days. This choice of treatments is based on the fact that some farmers use high doses as $800 \mathrm{~kg} \mathrm{ha}^{-1}$ and the second rate was half of that elevated rate. The difficulties to monitor the experiment, located about $1600 \mathrm{~km}$ from our laboratory, and the cost of the equipment, did not allow the use of a greater number of fertilizers doses. In order not to overlap the farm fertilizer $\mathrm{N}\left(600 \mathrm{~kg} \mathrm{ha}^{-1}\right)$ with the doses of the treatments, the $\mathrm{N}$ fertigation of circle 4 was discontinued during the whole year, and different doses of $\mathrm{N}$ were applied manually, using a water container with a solution volume equivalent to the irrigation depth of 4 $\mathrm{mm}$, simulating the LEPA application.

One ceramic suction cup was installed under the central tree of each replicate, at the depth of $1 \mathrm{~m}$, to evaluate the ${\mathrm{N}-\mathrm{NO}_{3}}^{-}$concentration $\left(\mathrm{C}, \mathrm{mg} \mathrm{L}^{-1}\right.$ in terms of $\left.\mathrm{N}\right)$, measured according to Giné et al., (1980) by FIA (Flow Injection Analysis). Monthly averages of the concentration of ${\mathrm{N}-\mathrm{NO}_{3}}^{-}$(transformed into $\mathrm{kg} \mathrm{kg}^{-1}$ of N$\mathrm{NO}_{3}^{-}$expressed as $\mathrm{N}$ ) were used to calculate leaching

Table 2. Soil water storage (SWS) and available water capacity (AWC) estimated through the van Genuchten (1980) model, as a function of depth; $\mathrm{q}_{330}$ is the soil water content at field capacity and $\mathrm{q}_{15000}$ at the permanent wilting point

\begin{tabular}{lcccc}
\hline $\begin{array}{c}\text { Depth } \\
\mathbf{m}\end{array}$ & $\begin{array}{c}\boldsymbol{\theta}_{\mathbf{3 3 0}} \\
\mathbf{c m}^{\mathbf{3}} \mathbf{c m}^{-\mathbf{3}}\end{array}$ & $\begin{array}{c}\mathbf{S W S}_{\mathbf{3 3 0}} \\
\mathbf{m m}\end{array}$ & $\begin{array}{c}\boldsymbol{\theta}_{\mathbf{1 5 0 0 0}} \\
\mathbf{c m}^{\mathbf{3}} \mathbf{c m}^{-\mathbf{3}}\end{array}$ & $\begin{array}{c}\mathbf{S W S}_{\mathbf{1 5 0 0 0}} \\
\mathbf{m m}\end{array}$ \\
\hline $0-0.2$ & 0.172 & 34.4 & 0.107 & 21.4 \\
$0.2-0.4$ & 0.169 & 33.8 & 0.102 & 20.4 \\
$0.4-0.6$ & 0.183 & 36.6 & 0.108 & 21.6 \\
$0.6-0.8$ & 0.214 & 42.8 & 0.114 & 22.8 \\
$0.8-1.0$ & 0.242 & 48.4 & 0.117 & 23.4 \\
\hline Total SWS & & 196.0 & & 109.6 \\
\hline AWC & & & & 86.4 \\
\hline
\end{tabular}

Table 1. Mechanical analysis of the soil as a function of depth

\begin{tabular}{ccccc}
\hline $\begin{array}{c}\text { Depth } \\
\mathbf{m}\end{array}$ & $\begin{array}{c}\text { sand (\%) } \\
\mathbf{2 - \mathbf { 0 . 0 5 }} \mathbf{~ m m}\end{array}$ & $\begin{array}{c}\text { silt } \mathbf{( \% )} \\
\mathbf{0 . 0 5 - 0 . 0 0 2}\end{array}$ & $\begin{array}{c}\text { clay }(\boldsymbol{\%}) \\
<\mathbf{0 . 0 0 2} \mathbf{~ m m}\end{array}$ & textural class \\
\hline $0-0.2$ & 81 & 3 & 16 & medium sandy \\
$0.2-0.4$ & 79 & 3 & 18 & medium sandy \\
$0.4-0.6$ & 74 & 3 & 23 & medium sandy \\
$0.6-0.8$ & 72 & 3 & 25 & medium sandy \\
$0.8-1.0$ & 70 & 2 & 28 & medium sandy \\
$0-1.0$ & 75.2 & 2.8 & 22.0 & - \\
\hline
\end{tabular}


amounts, multiplying them by the respective values of drainage soil water fluxes (transforming mm into $\mathrm{kg} \mathrm{ha}^{-1}$ of drained water at $1 \mathrm{~m}$ depth). The total leaching loss was represented by the sum of these 12 values.

The losses by fertilizers leaching based on one hectare of plantation have to take into account the effective area over which the fertilizer is applied, in our case, the plant row. The fertilizer application per plant was performed on an area of $1.90 \times 0.5=0.95 \mathrm{~m}^{2}$. Considering that the displacement of $\mathrm{N}^{-\mathrm{NO}_{3}}{ }_{3}$ in the soil profile would disperse over a greater area when reaching deeper depths, and would reach the center of the row at the $1 \mathrm{~m}$ depth, we assumed that the effective area for leaching is $1.425 \mathrm{~m}^{2}$ plant $^{-1}$.

\section{RESULTS AND DISCUSSION}

The coffee crop assessed in this study received periodical fertigations, and their contribution coupled with rainfall are shown in Table 5, which also contains estimated values of drainage soil water fluxes. The two models of potential evapotranspiration used in the climatologic water balance calculations lead not to very different values of drainage soil water fluxes. The climatologic water balance program does not allow the application of statistics, because only one climatic data set was used in the calculations for a given location, therefore, the differences between the use of Thornthwaite or Pennan-Monteith cannot be appreciated statistically. The accumulated values of drainage soil water fluxes for Thornthwaite and Pennan-Monteith were 891.1 and $1010.5 \mathrm{~mm}$, respectively, with a difference of just $11.7 \%$. However, such differences are well documented in the literature, so that we recommend Pennan-Monteith for locations where a more complete climatic data set is available, and Thornthwaite when the only accessible variable is the air temperature. Therefore, we decided to present from here on, average values of drainage soil water fluxes estimated by Thornthwaite and Pennan-Monteith.

Average concentrations of $\mathrm{N}^{-\mathrm{NO}_{3}}$, also shown in Table 5 , indicate that in a general way, for both treatments, there was a tendency to increase as expected, due to the continuous applications of urea, with occasional decreases in March, May and June. The March decrease can be attributed to a greater $\mathrm{N}$ demand by the crop during the

Table 3. Soil chemical analysis at different depths

\begin{tabular}{|c|c|c|c|c|c|c|c|c|c|c|c|c|c|c|}
\hline \multirow{2}{*}{$\frac{\text { Depth }}{\mathrm{m}}$} & \multirow{2}{*}{$\frac{\mathrm{pH}}{\mathrm{CaCl}_{2}}$} & \multirow{2}{*}{$\frac{\mathrm{MO}}{\mathrm{g} \mathrm{dm}^{-3}}$} & $\mathbf{P}$ & $\mathbf{S}$ & $\mathbf{K}$ & $\mathrm{Ca}$ & Mg & Al & $\mathrm{H}+\mathrm{Al}$ & SB & $\mathbf{T}$ & V & $\mathbf{m}$ & Total $\mathbf{N}$ \\
\hline & & & \multicolumn{2}{|c|}{$\mathrm{mg} \mathrm{dm}^{-3}$} & \multicolumn{7}{|c|}{$\mathrm{mmol}_{\mathrm{c}} \mathrm{dm}^{-3}$} & \multicolumn{2}{|c|}{$\%$} & $\mathrm{mg} \mathrm{L}^{-1}$ \\
\hline $0-0.2$ & 4.7 & 25 & 114 & 10 & 2 & 23 & 9 & 3 & 31 & 34 & 65 & 52 & 8 & 1080 \\
\hline $0.2-0.4$ & 3.6 & 20 & 40 & 21 & 1 & 5 & 3 & 9 & 34 & 9 & 43 & 21 & 50 & 620 \\
\hline $0.4-0.6$ & 3.8 & 16 & 5 & 60 & 0.8 & 4 & 2 & 9 & 31 & 6.8 & 37.8 & 18 & 57 & 532 \\
\hline $0.6-0.8$ & 3.6 & 14 & 1 & 72 & 0.8 & 3 & 1 & 9 & 31 & 4.8 & 35.8 & 13 & 65 & 520 \\
\hline $0.8-1.0$ & 3.8 & 14 & 1 & 96 & 0.8 & 2 & 1 & 10 & 31 & 3.8 & 34.8 & 11 & 72 & 505 \\
\hline $0-1.0$ & 3.9 & 17.8 & 32.2 & 51.8 & 1.1 & 7.4 & 3.2 & 8.0 & 31.6 & 11.7 & 43.3 & 23.0 & 50.4 & 631.4 \\
\hline
\end{tabular}

$\mathrm{MO}=$ organic matter, $\mathrm{P}=$ phosphorus, $\mathrm{S}=$ Sulfur, $\mathrm{K}=$ potassium, $\mathrm{Ca}=$ calcium, $\mathrm{Mg}=$ magnesium, $\mathrm{Al}=$ aluminum, $\mathrm{H}=$ hydrogen, $\mathrm{SB}=$ sum of bases, $\mathrm{T}=$ cation exchange capacity, $\mathrm{V}=$ base saturation, $\mathrm{m}=$ aluminum saturation.

Table 4. Rainfall (P), irrigation (I), average air temperature (T), average air relative humidity ( RH), solar net radiation (Rn) and wind speed $(\mathrm{V})$, for the evaluation period (DAB = days after beginning)

\begin{tabular}{|c|c|c|c|c|c|c|c|c|}
\hline \multirow{2}{*}{ Month/Year } & \multirow{2}{*}{ DAB } & $\mathbf{P}$ & I & $\mathbf{P}+\mathbf{I}$ & \multirow{2}{*}{$\frac{\mathbf{T}}{{ }^{\circ} \mathbf{C}}$} & \multirow{2}{*}{$\begin{array}{c}\text { RH } \\
\%\end{array}$} & \multirow{2}{*}{$\frac{\mathrm{Rn}}{\mathrm{MJ} \mathrm{m}^{-2} \text { day }^{-1}}$} & \multirow{2}{*}{$\frac{\mathrm{V}}{\mathrm{m} \mathrm{s}^{-1}}$} \\
\hline & & & $\mathbf{m m}$ & & & & & \\
\hline AUG/08 & 15 & 0.0 & 118.1 & 118.1 & 24.0 & 42.4 & 10.2 & 1.6 \\
\hline $\mathrm{SEP} / 08$ & 46 & 31.5 & 128.8 & 160.3 & 26.4 & 49.5 & 10.4 & 1.9 \\
\hline OCT/08 & 76 & 0.0 & 139.9 & 139.9 & 28.5 & 36.1 & 11.8 & 2.2 \\
\hline NOV/08 & 107 & 314.5 & 69.6 & 384.1 & 26.8 & 70.8 & 7.8 & 1.5 \\
\hline DEC/08 & 137 & 195.0 & 22.4 & 217.4 & 25.3 & 76.3 & 9.7 & 1.4 \\
\hline JAN/09 & 168 & 230.0 & 26.5 & 256.5 & 25.4 & 76.6 & 10.7 & 1.3 \\
\hline FEB/09 & 199 & 185.5 & 11.2 & 196.7 & 25.5 & 77.5 & 10.2 & 1.1 \\
\hline MAR/09 & 227 & 350.5 & 7.5 & 358.0 & 25.7 & 76.3 & 9.7 & 1.0 \\
\hline APR/09 & 258 & 108.5 & 26.1 & 134.6 & 24.7 & 83.5 & 7.9 & 0.9 \\
\hline MAY/09 & 288 & 67.0 & 48.5 & 115.5 & 23.7 & 78.1 & 8.0 & 1.0 \\
\hline JUN/09 & 319 & 52.5 & 46.6 & 99.1 & 22.6 & 76.2 & 8.4 & 0.9 \\
\hline JUL/09 & 349 & 0.0 & 52.2 & 52.2 & 22.2 & 69.9 & 9.3 & 1.1 \\
\hline Total & - & 1535.0 & 697.3 & 2232.3 & 25.1 & 67.8 & 9.5 & 1.3 \\
\hline
\end{tabular}

Rev. Ceres, Viçosa, v. 60, n.6, p. 785-792, nov/dez, 2013 
fruit filling stage (Neto et al., 2011). During May and June, as observed by Bruno et al. (2011), who determined that during this period, the coffee plants accumulate a greater quantity of $\mathrm{N}$ in the aerial part and fruit, also showing a greater concentration of $\mathrm{N}_{-} \mathrm{NO}_{3}^{-}$in leaf. During July, the increase in concentration of $\mathrm{N}^{-\mathrm{NO}_{3}}{ }^{-}$can be attributed to litter decomposition due to an expressive leaf fall from 265 DAB due to a low absorption of $\mathrm{N}$ by the plant. Coffee straw has C:N ratio of 31:1 (Ricci et al., 2010), and is a residue of rapid decomposition with a quick return of $\mathrm{N}$ to the soil as $\mathrm{N}^{-\mathrm{NO}_{3}}$.

Another important point related to the concentration of $\mathrm{N}_{-} \mathrm{NO}_{3}{ }^{-}$in soil solution (Table 5) is the maximum limit of $\mathrm{N}^{-\mathrm{NO}_{3}}{ }_{3}^{-}$for human consumption. Brazilian health legislation (Brasil, 2004; Brasil, 2008) establishes $10 \mathrm{mg} \mathrm{L}^{-1}$ of $\mathrm{N}^{-\mathrm{NO}_{3}}$ expressed as $\mathrm{N}$, as the maximum safe value for consumption. For $\mathrm{T}_{400}$, practically over the entire study period, this limit was not reached, exception made to July.
On the other hand, for $\mathrm{T}_{800}$, the limit was overcome during the whole period. The values of $\mathrm{N}_{-} \mathrm{NO}_{3}$ - in March and July were three times greater than the limit, and in February and April, the values reached the limit almost four times.

An overview of all variables involved can be seen in Figure 1. The high rainfall in November, with a corresponding great value of drainage soil water fluxes, did not result in a very elevated value of losses of $\mathrm{N}_{-} \mathrm{NO}_{3}{ }_{3}^{-}$ by leaching because at this time, little fertilizer had been applied. In March, when much fertilizer had already been applied, we can observe the peaks of losses of $\mathrm{N}_{-} \mathrm{NO}_{3}{ }^{-}$by leaching.

Monthly values of leaching losses of ${\mathrm{N}-\mathrm{NO}_{3}}^{-}$for $\mathrm{T}_{400}$ and $\mathrm{T}_{800}$ present the same tendency, following quite close the data of rainfall + fertigation and drainage soil water fluxes. Although our soil is classified as a Latosol, it has a high sand content (Table 1), thus presenting elevated leaching levels, mainly for high doses of fertilizers as in

Table 5. Rainfall + irrigation $(\mathrm{P}+\mathrm{I})$, deep drainage $(\mathrm{Q})$, nitrate concentration $\left[\mathrm{N}^{-\mathrm{NO}_{3}^{-}}\right]$expressed as $\mathrm{N}$ in soil solution for $\mathrm{T}_{400}$ and $\mathrm{T}_{800}$, at the $1 \mathrm{~m}$ depth during the study period (DAB = days after beginning)

\begin{tabular}{|c|c|c|c|c|c|}
\hline \multirow{3}{*}{ Month/Year } & \multirow{3}{*}{ DAB } & \multirow{2}{*}{$\mathbf{P}+\mathbf{I}$} & \multirow{2}{*}{ Q } & \multicolumn{2}{|c|}{ Concentration $\left[\mathrm{N}-\mathrm{NO}_{3}{ }^{-}\right]$} \\
\hline & & & & $\mathbf{T}_{400}$ & $\mathbf{T}_{800}$ \\
\hline & & \multicolumn{2}{|c|}{$\mathbf{m m}$} & \multicolumn{2}{|c|}{$\mathrm{mg} \mathrm{L}^{-1}$} \\
\hline AUG/08 & 15 & 118.1 & 21.7 & 0.00 & 0.00 \\
\hline SEP/08 & 46 & 160.3 & 7.0 & 0.00 & 0.00 \\
\hline ОСТ/08 & 76 & 139.9 & 0.0 & 0.00 & 0.00 \\
\hline NOV/08 & 107 & 384.1 & 223.9 & 2.20 & 8.87 \\
\hline DEC/08 & 137 & 217.4 & 121.4 & 2.87 & 15.85 \\
\hline JAN/09 & 168 & 256.5 & 132.8 & 3.12 & 20.34 \\
\hline FEB/09 & 199 & 196.7 & 79.2 & 7.49 & 39.76 \\
\hline MAR/09 & 227 & 358.0 & 246.8 & 3.33 & 29.82 \\
\hline APR/09 & 258 & 134.6 & 43.2 & 9.67 & 39.19 \\
\hline MAY/09 & 288 & 115.5 & 56.4 & 1.69 & 23.86 \\
\hline JUN/09 & 319 & 99.1 & 18.7 & 1.82 & 14.14 \\
\hline JUL/09 & 349 & 52.2 & 0.0 & 16.62 & 33.32 \\
\hline Total (average) & - & 2232.3 & 951.1 & $(5.42)$ & $(25.01)$ \\
\hline
\end{tabular}

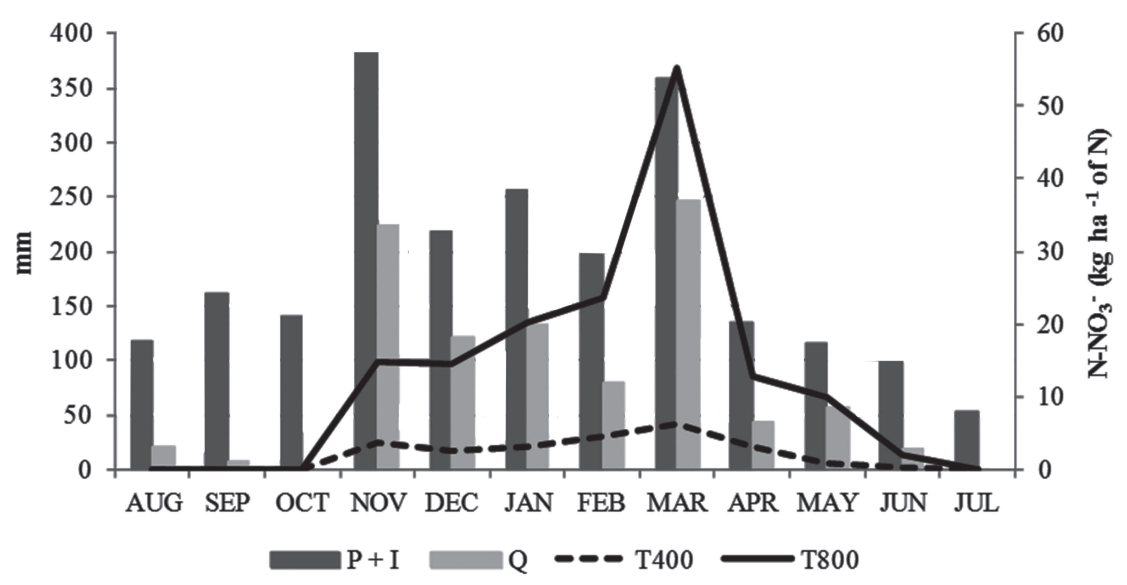

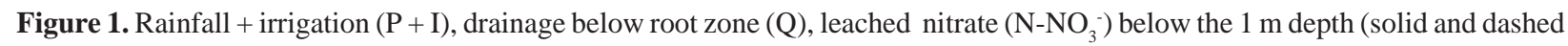
lines) for treatments $\mathrm{T}_{400}$ e $\mathrm{T}_{800}$. 
the $\mathrm{T}_{800}$ (Dynia, 2000). The maximum values of leaching

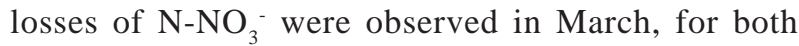
treatments, with slightly higher values for PennanMonteith in relation to Thornthwaite, with averages of $6.2 \mathrm{~kg} \mathrm{ha}^{-1}$ of $\mathrm{N}$ for $\mathrm{T}_{400}$, and $55.2 \mathrm{~kg} \mathrm{ha}^{-1}$ for $\mathrm{T}_{800}$. These losses are a consequence of the great values of drainage soil water fluxes combined to the large values of concentration, evidencing the narrow relation between the soil water movement and leaching of $\mathrm{N}^{-\mathrm{NO}_{3}}{ }_{3}^{-}$(Oliveira et al., 2001). However, Primavesi et al. (2006), state that peaks of losses of $\mathrm{N}^{-\mathrm{NO}_{3}}{ }_{3}^{-}$by leaching appear in the upper soil layer ( 0 to $40 \mathrm{~cm}$ ) preferentially after rainfall, mainly for those preceded by dry periods, independently of the application of $\mathrm{N}$ fertilizers. Araújo et al. (2004), cite that in a treatment which had received urea and lime leaching of $\mathrm{N}-\mathrm{NO}_{3}{ }^{-}$was greater as compared to a treatment that received only urea, with these treatments showing values much higher than the control.
Data of Table 5 show that the accumulated value of drainage soil water fluxes is of $951.1 \mathrm{~mm}$, which represents $42.6 \%$ of the sum rainfall + fertigation. Such high values of drainage soil water fluxes are typical for sandy soils under high input of water, showing a great potential for $\mathrm{N}$ leaching. For $\mathrm{T}_{400}$, the leaching loss of $\mathrm{N}^{-\mathrm{NO}_{3}}{ }_{3}^{-}$was $24.2 \mathrm{~kg} \mathrm{ha}^{-1}$ and for $\mathrm{T}_{800}, 153 \mathrm{~kg} \mathrm{ha}^{-1}$ of N$\mathrm{NO}_{3}^{-}$(Figure 2). In a study carried out by Oliveira et al. (2001), they observed losses over $100 \mathrm{~kg}$ de N-NO${ }_{3}^{-} \mathrm{ha}^{-}$ ${ }^{1}$ year $^{-1}$ for soils that received sewage sludge or even conventional $\mathrm{N}$ fertilization for sugarcane crop. For Araújo et al. (2004), such magnitude of leaching represents a risk for the environment. Furthermore, Dynia (2000) mentions that even in electro-positive soils with high clay content, the $\mathrm{N}^{-\mathrm{NO}_{3}}{ }^{-}$is capable to move out of the root zone of most crops, reaching depths between 2 to $6 \mathrm{~m}$ and finally accumulating there. Primavesi et al. (2006), states that the greatest variation

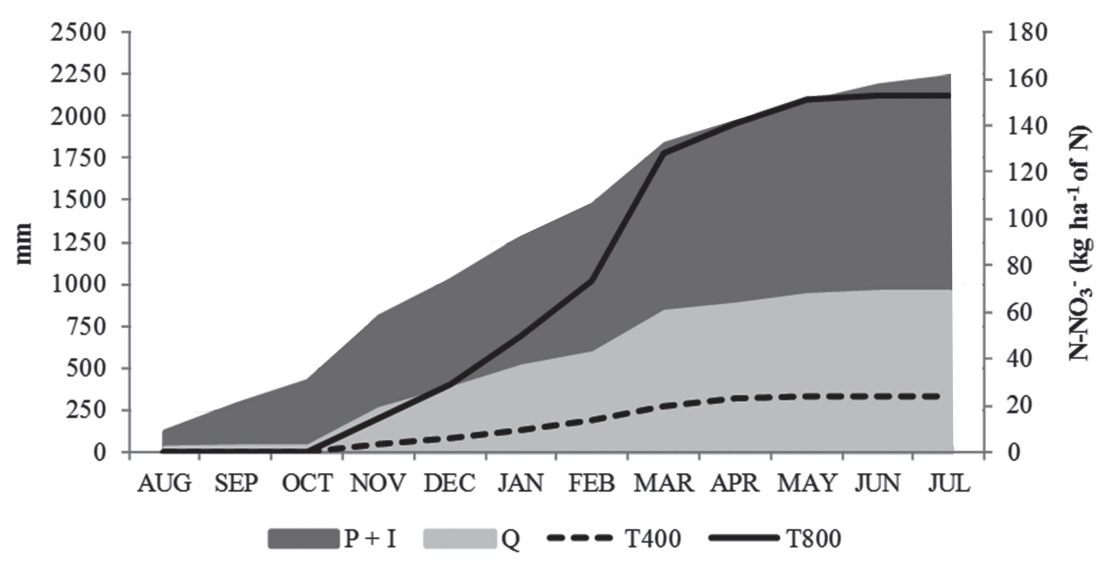

Figure 2. Accumulated values of rainfall plus irrigation $(\mathrm{P}+\mathrm{I})$, drainage below root zone $(\mathrm{Q})$, and quantities of nitrate $\left(\mathrm{N}-\mathrm{NO}_{3}\right)$ leaching (solid and dashed lines) for treatments $\mathrm{T}_{400}$ and $\mathrm{T}_{800}$.

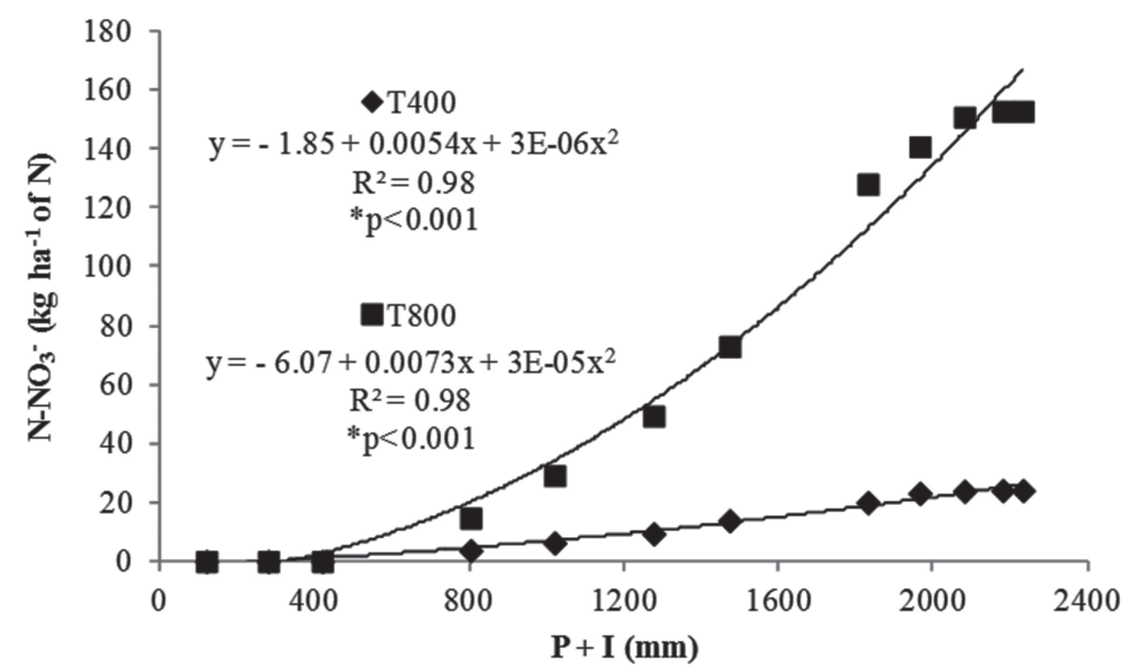

Figure 3. Correlation between accumulated data of rainfall plus irrigation $(\mathrm{P}+\mathrm{I})$ and nitrate $\left(\mathrm{N}_{-} \mathrm{NO}_{3}^{-}\right)$leaching for treatments $\mathrm{T}_{400} \mathrm{e}$ $\mathrm{T}_{800} *$ Significant at $\mathrm{p}<1 \%$.

Rev. Ceres, Viçosa, v. 60, n.6, p. 785-792, nov/dez, 2013 
of ${\mathrm{N}-\mathrm{NO}_{3}}_{3}^{-}$content happened in the top soil layers (down to $20 \mathrm{~cm}$ ) with a tendency of moving downwards to depths below $1 \mathrm{~m}$, in the case of applications of doses of $\mathrm{N}$ greater than $500 \mathrm{~kg} \mathrm{ha}^{-1}$ year $^{-1}$. This implies in more attention to $\mathrm{N}$ fertilizer management practices because it represents major concern due to economic and environmental issues (Araújo et al., 2004).

Accumulated data of losses of $\mathrm{N}^{-\mathrm{NO}_{3}}{ }^{-}$by leaching and the sum rainfall + fertigation show a very good correlation (Figure 3). It has to be mentioned that the calculations performed using the climatic water balance program considered the crop coefficient for coffee equal to 1 . The value of crop coefficient for coffee determines the maximum evapotranspiration, and therefore, affects the results of the excess calculated by the program, which is the estimative of drainage soil water fluxes in the described methodology. Crop coefficient for coffee values shown in the literature for coffee have a large variability, from 0.65 to 1.3 , due to differences in the methodologies employed for the determination, fenology, age of the crop, spacing and management practices (Pereira et al., 2002; Pereira et al., 2008; Santinato et al., 1996). Anyway, for different values of crop coefficient for coffee there will only be one direct relation between maximum evapotranspiration and drainage soil water fluxes. As an example, if maximum evapotranspiration is increased by a crop coefficient for coffee factor of 1.2 , drainage soil water fluxes will be reduced by a factor 0.8 . In this way, the data here presented for crop coefficient for coffee = 1 can be evaluated for any other crop coefficient for coffee.

\section{CONCLUSIONS}

Through the application of water and using the climatologic water balance was possible to evaluate the deep drainage below the root zone, in extremely flat areas (slope close to $0 \%$ ) and with very deep water table. In this way, it was possible to estimate the losses of $\mathrm{N}^{-\mathrm{NO}_{3}}{ }_{3}^{-}$by leaching.

The concentration of $\mathrm{N}^{-\mathrm{NO}_{3}}{ }_{3}^{-}$in the soil solution at $1 \mathrm{~m}$ depth, for a fertigated coffee crop that received $400 \mathrm{~kg}$ ha ${ }^{1}$ of $\mathrm{N}$, was on average $5.42 \mathrm{mg} \mathrm{L}^{-1}$, with one month surpassing the Brazilian legislation limit of $10.0 \mathrm{mg} \mathrm{L}^{-1}$. For a crop that received $800 \mathrm{~kg} \mathrm{ha}^{-1}$ of $\mathrm{N}$, the average value was $25.01 \mathrm{mg} \mathrm{L}^{-1}$, which is 2.5 times greater than this limit, indicating that rates above $400 \mathrm{~kg} \mathrm{ha}^{-1}$ of $\mathrm{N}$ are potentially polluting the ground water.

The yearly amounts of $\mathrm{N}^{-\mathrm{NO}_{3}}{ }^{-}$leached were 24.2 and $153.0 \mathrm{~kg} \mathrm{ha}^{-1}$ of $\mathrm{N}^{-\mathrm{NO}_{3}}{ }^{-}$for applications of 400 and $800 \mathrm{~kg}$ $\mathrm{ha}^{-1}$ of $\mathrm{N}$, respectively. This loss is six times greater in relation to the lower application rate and indicates a problem of cost/benefit for fertigations above $400 \mathrm{~kg} \mathrm{ha}^{-1}$.

\section{ACKNOWLEDGEMENTS}

The authors express their gratitude to $\mathrm{CNPq}$ and FAPESP for the financial support and fellowships.

\section{REFERENCES}

Allen RG, Pereira LS, Raes D \& Smith M (2006) Evapotranspiración del cultivo, Guías para la determinación de los requerimientos de agua de los cultivos. Roma, FAO. 298p.

Andrade EM, Aquino DN, Crisóstomo LA, Rodrigues JO \& Lopes FB (2009) Impacto da lixiviação de nitrato e cloreto no lençol freático sob condições de cultivo irrigado. Ciência Rural, 39:8895.

Araújo AR, Carvalho JLN, Guilherme LRG, Curi H \& Marques JJ (2004) Movimentação de nitrato e amônio em colunas de solo. Ciência e Agrotecnologia, 28:537-541.

Assadi ME, Clemente RS, Gupta AD, Loof R \& Hansen KG (2002) Impacts of fertigation via sprinkler irrigation on nitrate leaching and corn yield in an acid-sulphate soil in Thailand. Agricultural Water Management, 52:197-213.

Basso CJ, Ceretta CA, Durigon R, Poletto N \& Girotto E (2005) Dejeto líquido de suínos: II-perdas de nitrogênio e fósforo por percolação no solo sob plantio direto. Ciência Rural, 35:13051312.

Bortolotto RP, Bruno IP, Dourado-Neto D, Timm LC, Silva NA \& Reichardt K (2011) Soil profile internal drainage for a central pivot fertigated coffee crop. Revista Ceres, 58:723-728.

Bortolotto RP, Bruno IP, Reichardt K, Timm LC, Amado TJC \& Ferreira, AO (2012) Nitrogen fertilizer $\left({ }^{15} \mathrm{~N}\right)$ leaching in a central pivot fertigated coffee crop. Revista Ceres, 59:466-475.

Brasil. Ministério da Saúde (2004). Portaria n. 518, de 25 de março de 2004. O Ministério da Saúde aprova normas e padrões de potabilidade da água destinada ao consumo humano. Brasília, Diário Oficial, Seção I. p.266-270.

Brasil. CONAMA (Conselho Nacional do Meio Ambiente - Ministério do Meio Ambiente) (2008). Resolução n. 396, de 3 de abril de 2008. Dispõe sobre a classificação e diretrizes ambientais para o enquadramento das águas subterrâneas e dá outras providências. Brasília, Diário Oficial da União, Seção 1. p.64-68.

Bruno IP, Unkovich MJ, Bortolotto RP, Bacchi OOS, DouradoNeto D \& Reichardt K (2011) Fertilizer nitrogen in fertigated coffee crop: absorption changes in plant compartments over time. Field Crops Research, 124:369-377.

Correa RS, White RE \& Weatherley AJ (2006) Risk of nitrate leaching from two soils amended with biosolids. Water Resources, $33: 453-462$.

Dynia J F (2000) Nitrate retention and leaching in variable charge soils of a watershed in São Paulo State, Brazil. Communications Soil Science in Plant Analysis, 31: 777-791.

Embrapa (2006) Sistema brasileiro de classificação de solos. $2^{\mathrm{a}}$ ed. Rio de Janeiro, Centro Nacional de Pesquisa de Solos. 306p.

FAO (2010) Food and Agriculture Organization. Fertistat, Fertilizer Use Statistic. Disponível em: <http://www.fao.org/ag/agl/ fertistat/fst fubc en.asp> Acessado em: 10 dezembro 2011.

Giné MF, Bergamin H, Zagatto EAG \& Reis BF (1980) Simultaneous determination of nitrate and nitrite by flow injection analysis. Analytica Chimica Acta, 114:191-197.

Hansen B, Kristensen ES, Grant R, Høgh-Jensen H, Simmelsgaard SE \& Olesen JE (2000) Nitrogen leaching from conventional versus organic farming systems - a systems modeling approach. European Journal of Agronomy, 13:65-82. 
Jadoski SO, Saito LR, Prado C, Lopes E \& Sales LLSR (2010) Características da lixiviação de nitrato em áreas de agricultura intensiva. Pesquisa Aplicada \& Agrotecnologia, 3:193-200.

Milroy SP, Asseng S \& Poole ML (2008). Systems analysis of wheat production on low water-holding soils in a Mediterraneantype environment. II. Drainage and nitrate leaching. Field Crop Research 107:211-220.

Neto AP, Favarin JL, Almeida REM, Dias CTS, Tezotto T, Alves ALG \& Moraes MF (2011) Changes of nutritional status during a phenological cycle of coffee under highnitrogen supply by fertigation. Communications in Soil Science and Plant Analysis, 42:2414-2425.

Oliveira FC, Mattiazzo ME, Marciano CR \& Moraes SO (2001) Lixiviação de nitrato em um Latossolo Amarelo distrófico tratado com lodo de esgoto e cultivado com cana-de-açúcar. Scientia Agricola, 58:171-180.

Pereira AR, Angelocci LR \& Sentelhas PC (2002) Agrometeorologia: fundamentos e aplicações práticas. Guaíba, Agropecuária. $478 \mathrm{p}$

Pereira AR, Camargo AP \& Camargo MBP (2008) Agrometeorologia de cafezais no Brasil. Campinas, Instituto Agronômico. 127p.

Primavesi O, Freitas AR, Primavesi AC \& Oliveira HT (2002) Water quality of the Canchim's creek watershed, in São Carlos, SP, Brazil, occupied by beef and dairy cattle activities. Brazilian Archives of Biology and Technology, 45:209-217.

Primavesi O, Primavesi AC, Corrêa LA, Silva AG \& Cantarella H (2006) Lixiviação de nitrato em pastagem de coastcross adubada com nitrogênio. Revista Brasileira de Zootecnia, 35:683690

Ricci MSF, Neves MCP, Nannetti AN, Moreira CF, Aguiar-Menezes EL, Silva, É, Caixeta IF, Araújo JBS, Leal MAA, Fernandes MC, Almeida, PS, \& Pedini S (2010) Cultivo do café orgânico. Disponível em: <http://sistemasdeproducao.cnptia.embrapa.br/ FontesHTML/Cafe/CafeOrganico_2ed/anexo03.htm>. Acessado em: 16 julho de 2010.
Rolim GS, Sentelhas PC \& Barbieri V (1998) Planilhas no ambiente Excel $^{\mathrm{TM}}$ para os cálculos de balanços hídricos: normal, sequencial, de cultura e de produtividade real e potencial. Revista Brasileira de Agrometeorologia, 6:133-137.

Santinato R, Fernandes, ALT \& Fernandes DR (1996) Irrigação na cultura do café. Campinas, Arbore Agrícola e Comércio. 146p.

Scalco MS, Alvarenga LA, Guimarães RJ, Colombo, A. \& Assis GA (2011) Cultivo irrigado e não irrigado do cafeeiro (Coffea arábica L.) em plantio superadensado. Coffee Science, 6:193-202.

Silva AL, Roveratti R, Reichardt K, Bacchi OOS, Timm LC, Bruno IP, Oliveira, JCM \& Dourado-Neto D (2006) Variability of water balance components in a coffee crop in Brazil. Scientia Agricola, 63:105-114.

Sitthaphanit S, Limpinuntana V, Toomsan B, Panchaban S \& Bell RW (2009) Fertilizer strategies for improved nutrient use efficiency on sandy soils in high rainfall regimes. Nutrient Cycling in Agroecosystems, 85:123-139.

Soil Survey Staff (2010) Keys to Soil Taxonomy. 11 a ed. Washington DC, USDA-Natural Resources Conservation Service. $338 \mathrm{p}$.

Stewart LK, Charlesworth PB, Bristow KL \& Thorburn PJ (2006) Estimating deep drainage and nitrate leaching from the root zone under sugarcane using APSIM-SWIM. Agricultural Water Management, 81:315-334.

Superintendência de Estudos Econômicos e Sociais da Bahia - SEI (1998) Análise dos atributos climáticos do Estado da Bahia. Salvador, Superintendência de Estudos Econômicos e Sociais da Bahia. 85p.

Thornthwaite CW (1948) An approach towards a rational classification of climate. Geographical Review, 38:55-94.

Van Genuchten MT (1980) A closed-form equation for predicting the hydraulic conductivity of unsaturated soils. Soil Science Society of America Journal, 44: 892-898. 